\title{
The Desire for History in Lars von Trier's Europa and Theo An- gelopoulos' The Suspended Step of the Stork
}

By Angelos Koutsourakis

Spring 2010 Issue of KINEMA

\section{THE PERSISTENCE OF DIALECTICS OR THE DESIRE FOR HISTORY IN LARS VON TRIER'S EUROPA AND THEO ANGELOPOULOS' THE SUSPENDED STEP OF THE STORK}

In this article I intend to discuss cinema's potential to represent history in a period that political conflict and historical referents seem to be absent. I am going to pursue this argument through a comparative reading of two films, Lars von Trier's Europa (1991) and Theo Angelopoulos' The Suspended Step of the Stork (1991). My contention is that these two films exploit historical narratives of the past and the present with the view to negating teleological and ahistorical assumptions that history has come to a standstill.

The central topos of the postmodern theory is that the distinctions between real and fictional reference are not clear-cut and in order to gain an historical understanding one has to go beyond reductionist simplifications between facts and representations. This loss of historical specificity has been heightened by the collapse of a socialist alternative which provided for many years a sense of political conflict. European Cinema has responded in that loss of historicity in various ways. For the most part history becomes a fetish that puts forward a postmodern nostalgia that does not offer an understanding of the historical present. For instance, in Wolfgang Becker's Goodbye Lenin (2003) the East German past becomes a site of fascination stemming from the absence of overt concrete political conflict in contemporary history. The same applies for Florian Henckel von Donnersmarck's The Lives of the Others (2006), in which history is stripped off from its complexity and it serves as a means of asserting a clichéd superiority of the Western democracy over the former Communist regimes. However, the most sophisticated responses can be seen in the work of filmmakers that express a desire for history by resorting to the history of the cinematic medium itself. In this manner, the vanishing of historical/individual history into its representations is seen as a challenge, whose ultimate aim is to trace stable historical referents in a world that our understanding and comprehension of reality is highly related to representational images and stereotypes. To this category belong the films that I discuss.

Theo Angelopoulos and Lars Von Trier are very different directors and similar in many ways. Both are auteurs that elaborate specific thematic units through trilogies. The Suspended Step of the Stork is the first part of the 'Trilogy of Borders' followed by, Ulysses' Gaze (1995) and Eternity and a Day (1998). These films are meditations on the new political reality in Balkans after the fall of communism and they express melancholy over the unlimited circle of violence that followed the geopolitical changes in the area. Von Trier's Europa is the last film of Europa trilogy and is preceded by The Element of Crime (1984) and Epidemic (1987). The trilogy interrogates the historical past and present of Europe, expressing scepticism over its ability to erase historical traumas and move on to a hybrid reality.

This is an idea that connects Von Trier's and Angelopoulos' works which I am going to discuss. Before entering to an analysis of the aforementioned ideas, I consider it necessary to make a brief summary of the content of these movies, in order to guide the reader who is not familiar with them. The Suspended Step of the Stork takes place in a small town near the north of Greece that connects the country with its Balkan neighbours. The locals sardonically call the town 'the waiting room', because most of its inhabitants are refugees and asylum seekers that aspire to start a new life 'somewhere'. Alexandre (Gregory Karr), a TV reporter working in the town recognises in the face of a local (Marcello Mastroianni) a Greek politician who disappeared mysteriously after having resigned and published a book called Despair at the End of the Century. In his book he argued in favour of a need for a collective dream that could be a source of stimulation for social and political change. The film juxtaposes images of a refugee hybrid reality with the story of the journalist and the contentious persona of a local whose looks resemble the missing politician. Within a $\log$ shot, Angelopoulos has the journalist witnessing a wedding in the Greek-Albanian borders, in which the 
bride and her family are on one shore and the groom and his relatives on the other. When Alexander asks the politician's wife (Jeanne Moreau) to identify her husband, she responds laconically that it is not him, though the televised images that we are shown clearly demonstrate that he is the same person; this is a mystery which is not finally resolved. The film finishes with a stranger standing in the border line between Greece and Turkey with one step suspended in the air like a stork, saying: 'if I take one step I am somewhere else...or I die'.

Von Trier's Europa shares Angelopoulos' scepticism towards borders, hybridity, and the historical possibility of Europe after the fall of Communism, though in a completely different way. The film tells the story of Leopold Kessler (Jean-Marc Barr), a young American idealist of German origins who goes to post-war Germany to get a job and help in its reconstruction. His uncle will help him find work in Zentropa, a German railway company owned by Max Hartmann, a German businessman who sees the reconstruction of the German railway system as his sole reason for living and works in close cooperation with the allies. Eventually, Leo will face Germany's inability to erase its past, as well as the ambivalent role of the US occupation force authorities. In one of his first trips as a sleeping car conductor he witnesses the killing of a German official by a Nazi terrorist group named the Werewolves. Eventually he gets involved in a relationship with Katharina (Barbara Sukowa), Max Hartmann's daughter. Leo will be entangled in a situation beyond his control, being forced to plant a bomb in the train in which he works, so as to save his wife that has been kidnapped by the terrorists. Towards the end of the film, he realises that Katharina was part of that group and she just manipulated him. Having seen allies collaborating with former Nazis, a Jew making a false statement regarding the political background of Hartmann, Katharina being indirectly responsible for patricide and a member of the Werewolves, the young pacifist is transformed into a mass murderer, unintentionally setting off a bomb into the train.

Apart from the two films' thematic concern with European history, we can also identify formal similarities. The major one is the re-appropriation of familiar cinematic images. Angelopoulos' employment of actors as agents, nods to the history of modern cinema. Marcello Mastroianni and Jeanne Moreau signify with their appearance a reference to the modernist utopian vision of the 1960s and the European Art cinema, in an age that as the film suggests through the politician's words, a utopian collective dream is a historical necessity. Mastroianni's and Moreau's presence in the film echoes their previous relationship in Antonioni's film $L a$ Notte (1961). Christian Metz's idea of the actor as an agent can help us evaluate the intertextual effects created by the physical presence of an actor. Metz explains that the actors can act as agents and create an interaction between a cinematic and an extra-cinematic code. ${ }^{(1)}$ We can identify this in Europa which, as Thomas Elsaesser points out, looks more than a German rather than a Danish film, because of its setting, and Barbara Sukowa's background in Fassbinder's films. ${ }^{(2)}$ Seen this way, the presence of actors of a variety of backgrounds gives a sense of intertextuality that foregrounds the idea of approaching history by resorting to its representations. Von Trier has admitted that the background of an actor plays a major role in his films:

I feel that the past and the image of an actor mean a great deal. It's definitely something to take into account when you cast. If an actor has a back catalogue of work and even a private life that stands for something then of course he brings it into the film. And you can just as well work with these things, take advantage of them. ${ }^{(3)}$

Von Trier's comments can be seen in conjunction with Jean Baudrillard's concept of the simulacra. Baudrillard develops the notion of the simulacrum as a copy that does not have an original, arguing that there is no point in distinguishing between the real and the illusory, simply because the real is no longer possible. ${ }^{(4)}$ To claim though that all history has lapsed into representation would be mere nonsense; however it is important to comprehend how our understanding of historical narratives is mediated by images and stereotypes that saturate every day reality. Cinema's ability to connect us with the cinematic past and present has been acknowledged, albeit in a negative way, by Theodore Adorno's and Max Horkheimer's dictum that 'real life has become indistinguishable from the movies'. ${ }^{(5)}$ The question that concerns me is how one can represent history in a period that the categories between true and false events seem to have been suspended. As noted in the introduction a problem that can be observed in certain films that deal explicitly with historical material is that they do not represent historical relations but a hyper-resemblance of history that lacks any analytic thrust. 
Contrary to these practices that offer a de-historicised image of the world and fail to grasp the historical transitions, Von Trier's and Angelopoulos' response to the age of simulacra is much more subtle. Rather than expressing nostalgia for a lost world of historical transparency, they do exploit the contemporary difficulty in distinguishing between reality and fiction, revealing the prevalence of history. In The Suspended Step of the Stork, the formal choice of not representing the politician in the narrative real time, ${ }^{(6)}$ but only through televised archival material, invokes the uncertain historical relations and the changing function of politics that cannot be understood by resorting to individual figures. The missing politician is a simulacrum, namely a copy that does not have an original and the refusal to represent him points to a historical period, in which theories of subjectivity fail to produce historical knowledge. This neatly recalls the Marxist anti-humanist approach which asserts that a theory of the subject cannot clarify the social and historical relations. On this basis, the film presents the politician as an absent referent and disputes the idea that the subject can be an agent of history. On the contrary, collective history and memory - even cinematic memory - surpass and invalidate any notion of political practice as the result of individual decisions. Towards the end, the young journalist learns that the ambiguous local who resembles the politician has disappeared. The politician's wife states: 'I don't know if that is him or not, but I don't think it really matters anymore'.

Europa draws upon the notion of the unrepresentable in a different manner. The film takes place in postwar Germany, but the director does not provide us with any images of topical authenticity. Rosalind Galt in her discussion of the film has brilliantly captured the importance of such an oxymoron. She, therefore, relates Europa to Rossellini's Germania Anno Zero (1948), Billy Wilder's A Foreign Affair (1948) and finds similarities with these 'ruin films', highlighting the main difference between them and Europa, which is the omission of ruin shots. This device on the part of Von Trier, she claims, creates a spectacle that refuses identity and the coherence of a concrete narrative space, creating a cinematic space that goes against the discourse of a nation and the notion of ruin as a signifier of political progress. ${ }^{(7)}$ Galt considers that despite the direct references to the ruin films, the film creates a 'de-realization of space.' Furthermore, she equates the main character's inability to reach 'the real space of Germany' with the spectator's inability to see a realistic place and time of European post-war origin. ${ }^{(8)}$ On many occasions Leo attempts to see images of the 'real' Germanic post-war space, but there is always somebody or something to prevent him from doing so. During his first day in Germany Leo opens the curtains in the dormitory to see what is outside and he suddenly gets told off by his uncle, 'do you want to wake up all these people?' This motif has a sense of humour, since it shows Leo's inability to see 'the real Germany', the Germans' unwillingness 'to wake up', and their determination to forget their historical past. Later on in the train, Leo attempts again to open the curtains and his uncle intervenes too: 'Don't you dare look outside; there is nothing to see out there'.

The attempt to repress history is also exhibited in the scene where Katharina confesses to Leo her family's role in the transportation of Jews to extermination camps. Leo then is carried away by his wife's kisses and as they fall into bed, Katharina pulls down the curtain, hiding the barbed wire fences outside. ${ }^{(9)}$ Moreover, the willingness to forget the past is clearly demonstrated in a scene that problematises the temporality of the plot. Leo, willing to help the Hartmann family to bury Max, ends up in a wagon, full of emaciated people that are reminiscent of familiar images of Jews transported to the concentration camps. This scene does not serve an immediate narrative purpose, and it could be argued that it is a form of Brechtian Historisierung, with the view to signifying the remnants of fascism in contemporary reality. The fact that the plot-time is supposed to be taking place in the post-war Germany may bear out this assertion. By problematising the diegetic temporality, von Trier creates historicising effects that encourage a non-linear reading of history. History is shown as a farcical repetition of traumatic events. From this perspective, fascism cannot be relegated to the past and the triumphalist European narrative of progress is called into question.

Whereas Angelopoulos' movie refers directly to the European historical present, Europa does this in a roundabout way. Harlan Kennedy is a firm believer of this hermeneutical approach arguing that the film is about the present disguised as the past. Kennedy states that the representation of Europe in 1945 alludes to the 1991 reality of a continent searching for unity. ${ }^{(10)}$ Placing this historically we can trace the irony behind the fact that the film takes place in the disintegrated post-war Germany, whereas it was shot in a time that the resurgence of the animosities in Balkans led to the disintegration of the Yugoslavian Republic; at the same period Europe celebrated its federation. This contradiction between Europe's desire for unity and its inability to achieve it is highlighted by Angelopoulos' film too. In a long take that lasts over six minutes he 
shows a wedding ceremony taking place in the Greek and Albanian borders. The bride is on the one side of the river and the groom on the other. The ceremony follows the typical pattern of a Greek wedding ritual with the exchange of laurels and the blessings on the part of the Orthodox priest. However, its potency lies in the fact that the couple in the end remains split. As Andrew Horton observes:

The bride and groom remain separated by the border, each in a different country. They each raise an arm in greeting, the river flowing between them and they too, like a suspended stork remain "suspended" briefly, gazing at each other. ${ }^{(11)}$

This scene is shot in a purely cinematographic language, avoiding any dialogue and as Wolfram Schutte notes, it takes advantage of the dynamic impact of the early cinema. ${ }^{(12)}$ Like Von Trier, Angelopoulos expresses his scepticism over the historical future of Europe. A refugee's words 'We've crossed the border and we're still here. How many borders must we cross to reach home' contextualise the director's pessimism. Later the journalist speaking with a local colonel gets to know that the refugees instead of living harmonically, they fight each other for reasons that cannot be known, because nobody can understand their language. As he says: they crossed the borders to find freedom and they created new borders here'. Von Trier's and Angelopoulos' scepticism towards hybridity is quite central in their understanding of the inescapability of history. Contrary to the neoliberal concept of 'the end of history', they both elaborate on the repetition of the historical traumas and the vicious circle of violence.

The concept of the end of history as articulated by Francis Fukuyama is predicated on Socialism's inability to become a sustainable alternative against Capitalism, something that made him affirm that the historical process would be led to a close. ${ }^{(13)}$ Fukuyama's essay laid the groundwork for the neo-liberal optimism that Capitalism will thrive and societies will enjoy a world of unlimited circulation of capital, irrespective of borders and past conflicts. Europa denies such a teleological approach, showing the failure of Max Hartmann's dream of Zentropa railway becoming an international enterprise, something that reaches its climax in the end that the train is exploded. This ironic comment on the post-war German aspiration for a capital without borders points at the present historical conditions of Europe and clearly rejects the neoliberal belief in a hybrid affluent society that will erase its past conflicts. Apparently, Von Trier criticises this enforced European unity, which is strictly based on economic grounds. Mike Wayne in his discussion of the film says:

The advocates of hybrid identities tend to downplay history as they promote the productive possibilities of remaking the self. Conversely, and no less problematically, Europa's hostility to crossing boundaries and mixing categories and mother tongues leads it to presenting history as inescapable fate and the self as permanently fixed by the past. ${ }^{(14)}$

Both films' formal aspects vindicate Wayne's argument with regard to the inescapability of history, or what I prefer to call as the persistence of the dialectic. In a way, both movies foreground an ambiguity of vision. In The Suspended Step of the Stork the limits of representation become part of the thematic elaboration of the content. Alexander's quest for verifiable results is frustrated and when he discovers that certain aspects of history challenge the limits of comprehensibility he questions his own role: 'The only thing that I cared of was filming people and not understanding their emotions'. Apparently, Alexander's figure can be read as the director's double and connects the diegetic reality with the reality of the meta-text. The film's ending points to the director's intention to occlude explanations and demand a more productive approach on the part of the audience. On the one hand we are shown the televised image of the politician arguing for the new century's need for a collective vision followed by Alexandre walking in the Greek-Albanian borders while in the background we can discern thirteen poles, with men perched on their top attempting to connect the telecommunication lines between them. The interjection of these different materials denies a narrative resolution that would probably provide a one-dimensional approach to history.

Similarly, von Trier connects the reality of the narrative with the reality of the spectator's viewing so as to avoid reducing history to a spectacle stripped off from its dialectical complexity. The audience is placed at the centre of the action, something that can be best illustrated by the hypnotic voice-over, which simultaneously addresses the character and the audience. This device can be seen as a critique of the social function of the cinema and the audience's tendency to immerse themselves uncritically into the cinematic spectacle. Moreover, von Trier's employment of hypnosis follows the psychoanalytical technique of attempting to refamiliarise the patient/viewer with events that have been rendered strange, in order to overcome traumatic 
experiences. However, the film renders the overcoming of the trauma impossible and like Angelopoulos it occludes explanation replacing diegetic closure with narrative aperture opening itself up to the recipient's hermeneutical activity. Towards the end, following the explosion and the ensuing disaster, the narrator says:

In the morning, the sleeper has found rest on the bottom of the river. The force of the stream has opened the door and is leading you on. Above your body, people are still alive. Follow the river as days go by. Head for the ocean that mirrors the sky. You want to wake up to free yourself of the image of Europa. But it is not possible.

The voice-over addresses an unidentified 'you', which, as noted earlier, merges the character's identity with the viewer's. The last words on the part of the off-screen narration make it poignantly clear that it is the audience, namely the collective that cannot escape from the non-reconciled image of Europe and not simply the character. Hence, there is a troubling paradox: the voice-over appears as authoritative but it denies giving the audience a hermeneutical orientation defying at the same time the medium's ability to represent history in an objective way. History appears in a fragmented way, through snippets of familiar cinematic images that cast doubt on factual accuracy and on the understanding of history as a logical sequence of events structured upon causality. Seen this way, Europa does not make history visible in a concrete form, but presents it as a problem, as a material for thought that will only make sense through the collective collaboration on the part of the audience.

Similarly, Angelopoulos' narrative creates an ambiguity of vision that makes necessary the audience's participation in the production of meaning. Third person narration is mixed with first, whereas plenty of times we have the feeling that the diegetic addressee is the audience and not any of the fictional characters within the narrative. In the beginning of the film Alexander's off-screen narration tells us his experience of an incident in Piraeus, where some Asian refugees, having been denied asylum by the Greek government, decided to cast themselves in the sea. These lines do not have a diegetic function and it seems as if the director addresses the audience, making a preamble to the narrative. Similarly, towards the end Alexander quotes the missing politician's lines from his book: 'why can't we assume that today is December 31 1999?' Again, these lines cannot be necessarily attributed to a specific character and one cannot ascertain with certitude whether they function as a meta-filmic commentary or as part of the film's inner narrative. The effect is that different identities blend together creating a polyphonic effect, which puts forward the prevalence of history over the individuals together with a notion of it as a collective consciousness, which is not visibly accessible. In a way, Von Trier's and Angelopoulos' main subject is nothing but the interrelations between cinema and history. This point can be reinforced by placing emphasis on the inter-textual traits that can be identified in the Eur trilogy ${ }^{(15)}$ and on Angelopoulos' tendency to allude to mythologies from his native land and to cinematic memories created from his own works or from other modernist films. ${ }^{(16)}$ In many respects, this alternation between narrative and intertextuality, history and cinema, actors as characters and actors as agents, creates an ambiguity of vision that questions the medium's potential to capture the shifting and uncertain historical relations. The question that arises is, who narrates to whom and what? This ambiguity of vision that merges identities and obfuscates object relations is dedicated to the exposure of history as a collision of theses that challenges concrete vision and understanding.

In conclusion, The Suspended Step of the Stork and Europ make the representation of historical events problematic, in order to express an anxiety over a period that history saturates every aspect of life by appearing seemingly absent. This 'desire for history' can be seen in Von Trier's decision to explore the post-modern reality of the absent historical referents, by re-examining one of the major aspects of the European past, namely the repercussions of the Second World War. On the other hand, Angelopoulos deplores the absence of political conflict by adopting a non-triumphalist view of the post-communist reality. Correspondingly, such a desire for history is nothing but a desire for utopia. Utopia ( ) in its literal meaning signifies absence and as Fredric Jameson has suggested that utopian remedy is fundamentally a negative one and not just a vision of positive expectations. ${ }^{(17)}$ Thus understood, both films express negativity in the sense that they avoid the clichéd portrayal of history as a narrative with a beginning, middle and end, that is, as a fossil. On the contrary, they have to be seen under the rubric of history, mainly because they are formally and thematically concerned with the difficulties in representing it, denying at the same time the neo-liberal belief that political conflict belongs to the past. 


\section{Notes}

1. See Christian Metz, Language and cinema (The Hague: Mouton, 1974), p. 116. Here Metz discusses how a social code can be cinematized and survives outside a specific film continuing to be expressed outside of the textual system.

2. See Thomas Elsaesser, European Cinema: Face to Face with Hollywood, (Amsterdam: Amsterdam University Press, 2005), pp. 75-76.

3. Eva Af Geijerstam, 'A Conversation with Lars Von Trier, Henning Bendtsen and Ernst-Hugo Järegård', in Jan Lumholdt (ed), Lars Von Trier: Interviews (Mississippi: University Press of Mississippi, 2003) pp.64-70, here p. 67.

4. See Jean Baudrillard, 'The Precession of Simulacra', in Simulacra and Simulation (Ann Arbor: UMP, 1994), pp. 1-42, here p. 19.

5. Theodor Adorno \& Max Horkheimer, The Dialectic of Enlightenment (London: Allen Lane, 1973), p. 126.

6. One could interject that the politician is represented, because he is probably the same person with the local. However, this is not clarified by the narrative.

7. See Rosalind Galt The New European Cinema: Redrawing the Map (New York, Chichester: Columbia University Press: 2006), pp. 189-190.

8. See Galt, pp. 191, 221-222.

9. See Udi. E. Greenberg, 'The Holocaust Repressed: Memory and the Subconscious in Lars Von Trier Europa', in Film and History: An Interdisciplinary Journal of Film and Television Studies, 38:1 (2008), pp. 45-52, here p. 49.

10. See Harlan Kennedy, 'Europa/Zentropa', http://americancinemapapers.homestead.com/files/CANNES_1991.htm, accessed 21/10/08.

11. Andrew Horton, The Films of Theo Angelopoulos: A Cinema of Contemplation (Princeton, New Jersey: Princeton University Press, 1997), p.170.

12. Schutte quoted in Horton, p.169.

13. See Alex Callinicos, Theories and Narratives- Reflections on the Philosophy of History (Cambridge: Polity Press, 1995), p.15. Callinicos elaborates further Fukuyama's undialectical understanding of history, equating the bureaucratic socialism of the former Eastern block with the Capitalist reality of the West, arguing that what Fukuyama fails to understand is that the Eastern block did not actually embody a different social system from the West. For more on this see pp. 18-20.

14. Mike Wayne, The Politics of Contemporary European Cinema: Histories, Borders, Diasporas (Bristol: Intellect, 2002), p. 88.

15. Intertextuality in Europa is something that is beyond the scope of this article. Briefly, I mention some of the cinematic references that have been identified. Thus, Europa has been related to Fritz Lang's Metropolis, Visconti's The Damned, Orson Welles' Citizen Cane, Rossellini's Germania Anno Zero and Wilder's A Foreign Affair. For more on this See Galt, pp. 189-190 and Jan Simons, Playing the Waves. Lars Von Trier's Game Cinema (Amsterdam: Amsterdam University Press, 2007), p. 96.

16. Angelopoulos manipulates in his films myths that stem from the Ancient Greek tradition placing them in a historical context. For example in The Travelling Players, the history of modern Greece is seen through the refiguration of the myth of Orestes. In Megalexandros, he elaborates on the failed dream of a utopian society comparing the authoritarian figure of a contemporary leader to Alexander the Great. In his most recent works it is generally the myth of Odysseus that is used to allude to the individual's uncertain position 
in the current historical and topographical conditions.

17. Fredric Jameson, Archaeologies of the Future: the Desire called Utopia and other Science Fictions (London: Verso, 2005), p. 12.

\section{References}

Adorno, Theodore and Horkheimer Max, Dialectic of Enlightenment, (London: Allen, Lane, 1973).

Baudrillard, Jean, 'The Precession of Simulacra', in Simulacra and Simulation (Ann Arbor: UMP, 1994), pp. 1-42.

Callinicos, Alex, Theories and Narratives - Reflections on the Philosophy of History (UK: Polity Press, 1995).

Elsaesser, Thomas, European Cinema: Face to Face with Hollywood, (Amsterdam: Amsterdam University Press, 2005).

Europa directed by Lars Von Trier (Denmark, 1991).

Galt, Rosalind, The New European Cinema: Redrawing the Map, (New York, Chichester: Columbia University Press: 2006).

Geijerstam, Eva Af 'A Conversation with Lars Von Trier, Henning Bendtsen and Ernst-Hugo Järegård', in Lumholdt, Jan (ed), Lars Von Trier: Interviews (Mississippi: University Press of Mississippi, 2003), pp.64-70.

Greenberg, Udi E. 'The Holocaust Repressed: Memory and the Subconscious in Lars Von Trier Europa', in Film and History: An Interdiciplinary Journal of Film and Television Studies, 38:1, (2008), pp. 45-52.

Horton, Andrew The Films of Theo Angelopoulos: A Cinema of Contemplation (Princeton, New Jersey: Princeton University Press, 1997).

Jameson, Fredric, Archaeologies of the Future: the Desire called Utopia and other Science Fictions (London: Verso, 2005).

Kennedy, Harlan, 'Europa/Zentropa'

http://americancinemapapers.homestead.com/files/CANNES_1991.htm, accessed 21/10/08.

Metz, Christian, Language and cinema (The Hague: Mouton, 1974).

Simons, Jan, Playing the Waves. Lars Von Trier's Game Cinema (Amsterdam: Amsterdam University Press, 2007).

The Suspended Step of the Stork. Theo Angelopoulos (France, Greece, Italy, Switzerland, 1991).

Wayne, Mike, The Politics of Contemporary European Cinema: Histories, Borders, Diasporas (Bristol: Intellect, 2002).

\section{Author Information}

Angelos KOUTSOURAKIS is a doctoral candidate and an associate tutor at the University of Sussex, conducting research on the Brechtian dialectic and films of Lars Von Trier. He has published film and DVD reviews and is a member of NECS - European Network for the Promotion of Cinema and Media Studies. 